University of Nebraska - Lincoln

DigitalCommons@University of Nebraska - Lincoln

Faculty Publications, Department of History

History, Department of

October 2002

\title{
The Eastmans and the Luhans: Interracial Marriage between White Women and Native American Men, 1875-1935
}

Margaret D. Jacobs

University of Nebraska - Lincoln, mjacobs3@unl.edu

Follow this and additional works at: https://digitalcommons.unl.edu/historyfacpub

Part of the History Commons

Jacobs, Margaret D., "The Eastmans and the Luhans: Interracial Marriage between White Women and Native American Men, 1875-1935" (2002). Faculty Publications, Department of History. 13.

https://digitalcommons.unl.edu/historyfacpub/13

This Article is brought to you for free and open access by the History, Department of at DigitalCommons@University of Nebraska - Lincoln. It has been accepted for inclusion in Faculty Publications, Department of History by an authorized administrator of DigitalCommons@University of Nebraska - Lincoln. 


\title{
The Eastmans and the Luhans
}

\author{
Interracial Marriage between White Women and \\ Native American Men, 1875-1935
}

\section{MARGARET D. JACOBS}

At a lavish wedding and reception in New York City in 1891 Elaine Goodale, daughter of a prominent New England family, married Charles Eastman, a member of the Wahpeton band of the Santee Sioux (Dakotas). Writing in her memoirs Elaine declared, "I gave myself wholly in that hour to the traditional duties of wife and mother, abruptly relinquishing all thought of an independent career for the making of a home. At the same time, I embraced with a new and deeper zeal the conception of life-long service to my husband's people." Charles, a medical doctor, described himself a few months before their marriage by writing, "I was soon to realize my long dream - to become a complete man! I thought of little else than the good we two could do together." ${ }^{1}$ Both Charles and Elaine were members of a group of reformers who sought to solve the so-called Indian problem through assimilation, and they portrayed their marriage as a natural means to overcome Indian "backwardness" and poverty. The white woman would further uplift her already civilized Dakota husband, and the couple would work diligently to serve his people.

Fifty years later New York socialite Mabel Dodge moved to Taos, New Mexico, with her Russian émigré husband, the painter Maurice Sterne. Mabel soon became entranced with Tony Luhan, a Taos Pueblo Indian. Describing her feelings, Mabel wrote in her memoirs:

I had a strange sense of dislocation, as though I were swinging like a pendulum over the gulf of the canyon, between the two poles of mankind, between Maurice and Tony; and Maurice seemed old and spent and tragic, while Tony was whole and young in the cells of his body, with his power unbroken and hard like the carved granite rock, yet older than the Germanic Russian whom the modern world had destroyed. ${ }^{2}$

Mabel and Tony eventually divorced their respective spouses and married each other in 1923. In this case Mabel saw herself as a bridge between Tony's people 
and her own; she envisioned her marriage not as a vehicle by which to uplift and "serve her husband's people," but as a means to save her own race from the destruction wrought by the modern world.

The stories of the Eastmans' and Luhans' marriages contain all the necessary ingredients for two "racy" novels but they also provide more than voyeuristic romances. As Peggy Pascoe has written, "For scholars interested in the social construction of race, gender, and culture, few subjects are as potentially revealing as the history of interracial marriage." ${ }^{3}$ Both the Eastmans and the Luhans operated at the outer boundaries of American racial norms. Yet, through writing and speaking about their marriages, both couples worked to transform the racial ideologies of their times. Similarly both couples were bound by the gender norms of their respective eras but they also actively reshaped gender and sexual conventions.

The great majority of literature on interracial marriage has focused on laws forbidding interracial marriage and the court cases that ensued to challenge these laws. Another large part of the literature focuses on European and/or white American social attitudes toward interracial marriages. Until recently most studies of interracial marriage also focused almost exclusively on couples designated as white and black. ${ }^{4}$ This essay differs from such previous work in two important ways. First, I examine a little-studied configuration-white women and Indian men - and its changing meaning in American society. ${ }^{5}$ And second, rather than asking what white Americans thought about such liaisons, I instead consider how interracial couples themselves defended their choices and navigated the often-hostile terrain upon which they lived. I also examine the role interracial couples themselves played in reshaping public attitudes toward their marriages. It is, of course, impossible to generalize from only two such interracial marriages; this article should be viewed less as a definitive statement on the subject and more as a tentative step into the shallow end of a deep pool of material on the interplay between social currents, ebbing and flowing notions of gender and race, and interracial couples' own actions and movements to stay afloat.

Analyses of interracial unions comprise but one part of a new intellectual pursuit - critical race theory, an exploration of the changing racial categorization of ethnic "minorities" in the United States. Bolstering the work of scientists who have found no genetic or biological basis for racial categorization, critical race theorists have analyzed the adaptable, dynamic, and fabricated quality of race by studying how certain groups who were once considered nonwhite eventually became white, enjoying all the privileges that attended advancement in the racial hierarchy. ${ }^{6}$ Studies of interracial love, sex, and marriage between peoples categorized as Asians, American Indians, African Americans, 
Mexicans, and whites have complicated our understanding of the way that racial categories are constructed, dismantled, and reassembled. ${ }^{7}$

Such studies have made it increasingly difficult to use racial terms such as "white," "black," and "Indian" without quotation marks or tedious sentence structures. Yet if such terms have no objective basis, they nevertheless retain their power as terms derived from historical and social processes. As George Frederickson puts it, "It would be a mistake to infer that, once invented, [race does] not become durable and enormously influential." ${ }^{8}$ I use such racial terms in this article to denote socially and culturally contrived designations that have deep historical roots in American society.

As Pascoe argues, a study of interracial marriage can also yield a greater understanding of the construction of gender norms as well. Just as with the study of race, women's historians and other feminist theorists have for decades documented the fleeting nature of gender norms and argued that gender is not a fixed set of notions that directly correlates with biological differences between the male and female sex. ${ }^{9}$ Many scholars of intermarriage have ignored gender; they have made little distinction between attitudes toward and laws aimed at relationships between white men and nonwhite women and those directed toward unions between white women and nonwhite men. ${ }^{10}$ But, as a growing number of other historians have shown, American society has had markedly different attitudes toward interracial marriage depending on the gender of the white person involved. In general, interracial relationships between white men of the colonizing, dominant group and nonwhite women of colonized, conquered, and/or enslaved groups have been tolerated. Although laws in many colonies and states forbid interracial marriage between white men and black women, for example, many white slave owners commonly engaged in forced sex, concubinage, and informal relationships with their female slaves without social opprobrium. ${ }^{11}$ As we shall see, relationships between white men and Indian women were similarly tolerated within American society. Liaisons between white men and nonwhite women did not violate the hierarchical order that developed between European Americans, African Americans, and American Indians. Rather, they represented extensions and reinforcements of colonialism, conquest, and domination.

As David Fowler, Kathleen Brown, and Martha Hodes have pointed out, however, white Americans were much more threatened by interracial sex and marriage that involved white women and nonwhite men. Where there was a higher incidence of such liaisons, as in Virginia and Maryland, colonies and states were much more likely to pass laws against interracial marriage. ${ }^{12}$ When white women and nonwhite men engaged in sexual relationships or married, they violated the colonial, racial, and patriarchal order. Within this order, 
white men dominated both their daughters and wives as well as groups of subjugated peoples, including American Indians and African Americans. By law, white women were economic, social, and sexual possessions of white men, therefore, a nonwhite man who "possessed" a white woman undermined the gendered and racialized dominance of white men. The children of such unions also threatened the social order, especially since southern colonies had conveniently passed laws establishing that children followed the condition of their mothers. Thus a union between a white woman and a nonwhite man could allow a child of a "Negro" or Indian man to be legally white.

In the history of the mainland United States, forty-two states, colonies, or territories passed laws against marriage between people categorized as belonging to different races. Most legislatures focused on relationships between whites and "Negroes" or "mulattos," but three colonies and fourteen states prohibited marriages between whites and Indians. Louisiana and North Carolina also banned marriages between Indians and "Negroes." Twelve states or territories forbid marriages between "Orientals" and whites. ${ }^{13}$ Yet if laws against interracial marriage were not as common for Indian-white couples as for black-white couples, social taboos could be as powerful as legislative acts in shaping the lives of white women and their Indian husbands or lovers.

In the colonial era in American history there was widespread opposition to marriage between white women and Native American men. In fact, it was assumed that, as Brian Dippie explains, "The white woman would ordinarily be the unwilling victim in a union consummated through force-that is, as the captive ravished by her Indian captor, her body defiled, her spirit still pure." 14 According to historians Native Americans did use captivity to avenge the deaths in war of tribal members or to replace lost family members. Some captives were tortured and put to death; others were ritually adopted and could become full-fledged members of the tribe. Captive girls and young women were more likely to be adopted than killed, and many went on to marry and raise families among their captors. English colonists were surprised and alarmed by the numbers of English captives who chose to remain with their Indian captors, even when given the chance to be "redeemed." In one famous case in 1703, Eunice Williams was captured at age seven along with her entire family from Deerfield, Massachusetts. At age sixteen she married a converted Catholic Mohawk Indian from the Kahnawake Mission in Canada and the couple had at least two daughters who married Indian men. Until her death at age ninety-five, Eunice "preferred the Indian mode of life, and the haunts of Indians, to the unutterable grief of her father and friends." ${ }^{15}$

Significantly, white opposition in the colonial period to marriages between 
white women and Indian men seemed to have centered more on differences of religion than on conceptions of race or skin color. Eunice Williams's family objected to her marriage to a Mohawk man more because he did not share the Puritan religion than because he was Indian. Her family repeatedly sought to "redeem" her, that is, to bring her back into the Puritan fold. ${ }^{16}$ From the late eighteenth through the nineteenth centuries, however, new objections by whites surfaced that were based more on a belief in insurmountable biological and physical differences between Indians and whites. This change in attitudes is well illustrated in an episode that occurred in Cornwall, Connecticut, in the 1820s. Two young Cherokee men, John Ridge and Elias Boudinot, had converted to Christianity and been sent to study at the Cornwall Foreign Mission School. Both men fell in love with and eventually married white women. The townspeople were incensed and demanded that the Foreign Mission School close. After their wedding Ridge and his bride, Sarah Northrup, had to be hustled into a coach and at every station stop from Cornwall back to Cherokee country in present-day Georgia crowds of angry people jeered the young couple. The editor of one Connecticut newspaper remarked that some people believed Sarah "ought to be publicly whipped, the Indian hung, and the [girl's] mother drown'd." Once news of Elias Boudinot and Harriet Gold's engagement leaked out, Harriet had to be hidden in a neighbor's house for protection. On the village green, in full view of both her hiding place and her parents' home, two young men laid an effigy of Harriet on a funeral pyre; her own brother lit the fire. ${ }^{17}$

In contrast, white American attitudes toward white men who took Indian concubines or wives in the period before the Civil War were much more lenient. The attitude toward such men was a sense of mild disapproval and sympathetic understanding; since these men lived in remote frontier outposts where there were few white women, they simply had to take Indian women as last resorts. ${ }^{18}$ According to Richard Slotkin, white Americans gradually transformed the white frontiersman who consorted with Indian women into a "hero rather than a racial traitor." Because these frontiersmen were so integral to English colonization of the North American continent eventually their liaisons with Indian women were excused and even largely ignored. ${ }^{19}$

In contrast, why were unions of white women and Indian men seen as so scandalous and threatening? Clearly it was no longer a religious issue. John Ridge and Elias Boudinot were practicing Christians who were training to convert other Cherokees to Christianity. By the 1820 s a notion had emerged that there was an essential biological difference between Indians and whites, and it made many whites recoil in disgust and dismay from such marriages. A white woman who preferred a "savage" over one of her own "blood" upset the sup- 
posedly natural racial order, that the "civilized" white conqueror maintained superiority over the "savage red-skinned" Indian.

Interracial relationships between white women and Indian men also threatened predominant nineteenth-century American views of gender relations. America still operated under the notion of the feme covert; when a woman married she became entirely "covered" by her husband. Any property she brought to the marriage as well as her legal identity became subsumed under her mate's. As Linda Kerber has shown, a married woman possessed no independent relationship to the state; her position was constantly mediated through that of her husband's. Thus, to a society that adhered to the feme covert, a white woman who married an Indian would become Indian. The local Cornwall newspaper editor, in fact, argued that through marrying John Ridge, Sarah Northrup "had thus made herself a squaw." ${ }^{20}$ White men would lose their patriarchal power over a white woman who married an Indian, and, in the process, Indian men would gain a power and a prerogative that many white men believed should be theirs alone. The status of any children born to such interracial couples also troubled white Americans. As with the children of white masters and their black slave women, it was assumed that the children of white men and Indian women were Indian. But what of the children of white women and Indian men? Should they follow the condition of their mother? Should such mixed-race children be granted the status and privilege of whiteness? Neither white nor Indian, such children made a mockery of racial categories, revealing their instability and impermanence.

Yet not all white Americans subscribed to these views. A sizable number of social activists and other public figures embraced a more environmentally and culturally determined view of racial difference. In the meeting between white women and Indian men, they suggested that Indian men might be positively influenced to move toward "civilization." Lydia Maria Child, abolitionist and women's rights advocate, published Hobomok in 1824. This novel was set during the first decades of the Massachusetts Bay Colony, in which the heroine of the story, Mary Conant, marries an Indian. Although Mary's father disapproves of her choice of mate, her white friend Sally believes Hobomok "was the best Indian I ever knew. . . . He seems almost like an Englishman." ${ }^{21}$ Child's novel intimated that intermarriage between whites and Indians could serve as a positive force for transforming Indians into Englishmen or whites. As a feminist, Child did not adhere to the notion that a white woman who married an Indian man would take on his condition, that is, become an Indian. Instead, the woman would maintain her civilized position and serve as a guiding influence on her Indian husband.

By the second half of the nineteenth century, Child's belief that white 
women might civilize Indian men through marriage had gained greater currency. After the Civil War a movement of white reformers emerged that had become intensely interested in righting the wrongs that had been inflicted upon American Indians. This group of reformers quickly became convinced that isolating Native Americans on reservations was not the solution to the "Indian problem." Rather, they insisted, assimilation was the answer. If Indians could be uplifted and civilized, they believed, the United States would no longer have a significant number of impoverished, backward, and wronged people living off the government. ${ }^{22}$ To some reformers, adopting Child's view, interracial marriage between white women and Native American men offered a "natural" way of assimilating Native Americans. Elaine Goodale seems to have grown to share this viewpoint.

Elaine had been raised in a stable, middle-class home in New England. As a young adult she went to work at Hampton Institute, General Samuel Armstrong's school in Virginia for newly emancipated African Americans and newly conquered Plains Indians. Teaching English to former Lakota warriors, Elaine became convinced that the only way Indians could survive in the modern world was through education..$^{23}$ In 1885 , longing to see the Indian country where many of her students came from, she set off on a tour of the Dakota Territory. At the age of twenty-two Elaine convinced the Episcopal Bishop in Dakota Territory to allow her to set up a school in the White River Camp on the Lower Brulé Sioux reservation. In 1889 she took a respite from her work among the Lakotas and returned home to write articles and give paid lectures regarding her experiences and perspectives on Indian life and policy. When Thomas Morgan became the commissioner of Indian affairs he favored a more systematic system of government-run day schools and appointed Elaine Supervisor of Education in the Dakotas where she was responsible for overseeing sixty schools spread out across hundreds of miles. ${ }^{24}$

In 1890, as a new Ghost Dance movement spread to the Plains Indians, local whites and the new Indian agent reacted with alarm because they believed the Ghost Dancers were preparing for war rather than praying for a return to their traditional way of life. As white concern grew into hysteria the government agent closed all the schools and ordered all government employees, including Elaine, and "friendly" Indians to report to the Pine Ridge Agency. Feeling that they were unnecessarily being held under martial law, Elaine pleaded with agency officers to let the so-called "Friendlies" return home and to reopen the day schools. Instead, white alarm over the Ghost Dance increased. Elaine busied herself by preparing a Christmas celebration for the Lakotas at the agency. ${ }^{25}$ In the meantime she also met the new agency physician, Dr. Charles Eastman. 
Charles Eastman, named Ohiyesa by his Lakota family, was a member of the Wahpeton band of the Santee Sioux (Dakotas) who lived in present-day Minnesota. His mother died shortly after his birth, leaving him to be raised in a very traditional manner by his paternal grandmother. In 1862 a band of disgruntled Santee Sioux rose up in rebellion and killed many white settlers in the area when the Indian agent failed to deliver rations on time but prohibited the starving Sioux from hunting game off the reservation. After this incident, known as the Minnesota Massacre by local white families, Ohiyesa fled with his uncle and grandmother across the Canadian border and lived in Manitoba until he was fifteen. Both Ohiyesa and his uncle believed that Ohiyesa's father, Many Lightnings, had been captured by the U.S. army and executed. However, Many Lightnings had been pardoned by President Lincoln. Shortly thereafter he converted to Christianity, changed his name to Jacob Eastman, and took up a homestead in Flandreau, South Dakota. ${ }^{26}$

When Ohiyesa was fifteen and just completing a coming-of-age vision quest, his father came to retrieve him in Manitoba. Believing it part of his destiny, Ohiyesa returned to Flandreau with his father and became Charles Eastman. From there he embarked on a journey from Santee Normal School to Beloit College, Knox College, Dartmouth College, and finally to Boston University Medical School. Shortly after Charles graduated from medical school, he secured a position with the Bureau of Indian Affairs (BIA) and was sent to Pine Ridge Indian Agency. He arrived in 1890 in the midst of the growing hysteria over the Ghost Dance. ${ }^{27}$ As the crisis grew Charles and Elaine became acquainted and soon fell in love. Charles was attracted to Elaine's sincere interest in Indians and her ability to speak Dakota fluently. He felt a commonality with her that transcended their different cultural backgrounds. Her ideals, he said, "seemed very like my own," and her childhood had been spent "almost as much out of doors as mine." ${ }^{28}$ They announced their engagement on Christmas Day, 1890.

Four days later hundreds of Lakotas were killed at the Wounded Knee Massacre. As agency doctor Charles attended the victims and few remaining survivors of the massacre, while Elaine assisted as his nurse. The tragedy seemed only to bring them closer, and they married six months later. She gave up school teaching and her reform work to bear and raise their six children and keep house. He alternated over the next several decades between practicing medicine, organizing Indian affiliates for the YMCA, and working for the Bureau of Indian Affairs. He also became a frequent lecturer and prolific writer on Indian affairs and culture. ${ }^{29}$

Charles and Elaine seem to have been motivated to marry by powerful physical, intellectual, and spiritual attractions. In Charles's book, Old Indian Days, 
he related the story of a man named Antelope who fell in love with a woman from the enemy tribe. As he described it, "Their marriage, they believed, was made by a spirit, and it was holy in their minds. Each had cast away his people and his all for the sake of this emotion which had suddenly overtaken them both with overwhelming force." Antelope and his bride planned to live in seclusion away from each of their people. However, once they had a son, each wanted him to be part of their own tribe's people. Eventually the couple determined to return to her people. ${ }^{30}$ This tale may convey some hint of how the Eastmans saw their own marriage.

While their marriage appears to have been truly based on mutual attraction, the couple may have often been compelled to justify themselves to a hostile and intolerant public. Imperialism, social Darwinism, nativism, and the emerging "science" of eugenics all spurred white supremacy in this period. ${ }^{31}$ In its American form, eugenics originated in the late nineteenth century but became increasingly popular in the first decades of the twentieth century. At the First Universal Races Congress held in London in 1911 one eugenicist asserted that "mankind can solely or mainly be improved in the only manner that animals can - that is, by careful selection or breeding." 32 Eugenicists at the Universal Races Congress divided over the advisability of race mixing between "whites" and "non-whites." Already ranking Indians and blacks far below whites, some theorists believed race mixing would result in progeny with even worse genetic makeups than full-blood Indians or pure blacks. Others believed that "half-breeds are not able to compete [in many qualities] with the stronger races of the Aryan stock, [but] ... it is none the less certain that we cannot place [them] at the level of really inferior races." ${ }^{33}$ A rare few asserted that race mixing resulted in a "superior type." ${ }^{34}$ Sharing the common eugenicist view many white Americans looked askance at marriages between white women and Indian men, primarily because they believed the "Indian problem" to be a problem of biology. To this group of Americans Indians were biologically inferior to and different from native-born, white Protestant Americans, and segregation (or sometimes extermination) appeared to them to be the only solution to the Indian problem.

This was the controversial climate into which the Eastmans married and bore six mixed-race children. To defend themselves, the couple justified their marriage publicly as a natural means to assimilate the Indian. In a speech at the First Universal Races Congress, Charles articulated this philosophy. "Since it is admittedly impossible for the Indian to continue to exist as a separate race, with his proper racial characteristics and customs, within the limits of the United States," he asserted, "race amalgamation is the only final and full solution of the problem, and only in this sense, implying no lack of vitality, but 
quite the reverse, is the American Indian a 'dying race." 35 Many missionaries and reformers concerned with Indian affairs shared this view, perceiving the "Indian problem" primarily as a matter of environment rather than a biological problem.

The couple's support for amalgamation took on a very personal as well as a very public dimension. Charles remarked in his memoirs that "our greatest personal concern [was] the upbringing and education of our children." 36 It must have been difficult for him to listen to the myriad academic theories and eugenic pronouncements at the Universal Races Congress. In his own speech he vigorously defended interracial marriage and the children these unions produced:

The common slur which attributes to the mixed-blood "the vices of both race and the virtues of neither" is absolutely unjust.... Within the past twenty or thirty years ... there have been a great many inter-marriages ... between educated Indians and Caucasians; and whereas in the early days only Indian women contracted these alliances, of late years almost as many Indian men choose Anglo-Saxon wives. Such marriages, based upon mutual sympathy and affection, have been generally happy and have had the best results. ${ }^{37}$

Charles was not being quite truthful. He and Elaine were having troubles. As early as 1894 there were rumors of incompatibility between the two. ${ }^{38}$ Both chose not to write about these troubles or to destroy all record of them. Perhaps, as a couple who upheld themselves as an example of the assimilating power of interracial marriage, they did not wish to illuminate their difficulties. Yet stories that the two coauthored seem to provide important hints regarding the ups and downs of their cross-cultural marriage. In Wigwam Evenings, one story concerns a man who married a Bear Woman, was deceived by her, and almost eaten by her relatives. Were the Eastmans referring to their own marriage and the possible feeling of being eaten up by each other's communities when they wrote, "This story is told for a warning to those who wish to marry among strangers?" 39

In 1921, after thirty years of marriage (many of which appear to have been unhappy), the Eastmans separated for good. Charles divided his time between a cabin in Ontario and his son's home in Detroit. Elaine lived out the remainder of her life in Massachusetts. Based partly on interviews with Eastman descendants, Charles's biographer Raymond Wilson asserts that Charles resented his wife's interference in his writing and her supposedly domineering manner. Wilson also discovered that Charles was known as a philanderer. ${ }^{40}$ Beyond these highly personal conflicts, I believe there were also more philosophical differences between the two. 
When the couple married they seemed to share a view of the proper roles of men and women and a view of the best solution to the so-called Indian problem. Over time, however, Elaine seems to have become embittered by the sacrifices she felt that she made to carry out the proper role of a woman. She also seems to have grown angry with her husband for failing to live up to her vision of the male role. Charles seems to have become resentful of the demands of Christianity and civilization and the loss of many aspects of his cultural heritage. Foremost among these was his sense that he had lost his manhood. As I explore below, it appears that his vision of manhood significantly conflicted with Elaine's.

By virtue of her childhood and her early career as a schoolteacher, writer, and Indian reformer, Elaine seemed destined to join the large number of white women reformers of the late nineteenth and early twentieth centuries who made new public spaces and careers for themselves. ${ }^{41}$ Yet she claims that, ironically, her feminist mother withheld her support for Elaine's career plans. "Mother failed, indeed, to sympathize with my plans or my enthusiasm," Elaine lamented, "but neither she nor any one else proposed a satisfying alternative." 42 Even without her mother's support Elaine might have attained the public career she craved. But her course was altered further when she met and married Charles. Elaine said and wrote little about her marriage at the time, but one speech she made to the Lake Mohonk group of reformers in 1895 is perhaps revealing. Speaking of Indian women she remarked, "What I like about the Indian woman is that she is so womanly. I hope it will be a long time before she becomes so advanced as to desire any better career than that which culminates in motherhood." 43 At the time Elaine might have willingly sacrificed her burgeoning career to marry and to raise six children.

Charles had his own ideas about how women should behave, from both his own culture and from his inculcation in white American social values. In Part Two of Old Indian Days, called "The Woman," Charles conveyed these ideas: "The Indian woman in her quiet way preserves the dignity of the home. From our standpoint the white man is a law-breaker! ... [The woman] is the foundation of man's dignity and honor. Upon her rests the life of the home and of the family." ${ }^{44}$ At least at the beginning of their marriage, Charles's view of the proper role of a woman meshed with Elaine's.

In later years, however, Elaine developed a different view of her marriage and her role within it. In several articles and her autobiography she writes with an unmistakable bitterness about her marriage. She asserts that "for fifteen years I handled nearly all the correspondence and publicity incident to twentyfive or more annual appearances" of her husband. Furthermore, she claims to have cowritten every book attributed to Charles alone. In a 1939 letter she asserted, "Dr. Eastman's books left his hand as a rough draft in pencil, on scratch 
paper. From this I made two or three typed copies, revising, omitting and rewriting as necessary." 45 In her autobiography, she revealed how much her backstage role frustrated her:

No, I won't say that the adjustment was easy or that I was never lonely, restless, and haunted by a secret sense of frustration. Every woman who has surrendered a congenial task and financial independence will understand. Saving the joys of motherhood, my pleasures must be vicarious ones. He traveled widely, ... and met hosts of interesting people. I was inevitably house-bound. ... For many a year every early dream and ambition was wholly subordinated to the business of helping my talented husband express himself and interpret his people. Whether or not this was wise is perhaps an open question. Obviously, it was far from modern. ${ }^{46}$

Elaine might have been happy to play the role she felt was appropriate to her sex had Charles been playing the role she felt was appropriate to his, that of breadwinner. At several points in her autobiography and articles she lets slip her disappointment in his inability to fulfill this role. She had to write a "few 'pot boilers' for our income was never at all adequate to the family needs." She also accused her husband of engaging in a "series of dubious experiments." Charles did, indeed, have difficulty holding down a steady job, at least partly due to the prejudice against him as well to his own growing disillusionment with the BIA. After the couple married he returned to his position with the BIA at Pine Ridge but when he protested that many of the reservation's inhabitants had been cheated out of their depredation claims, he was transferred. Instead of accepting the transfer, he resigned from the BIA and started a private medical practice in St. Paul, to which he attracted few patients. Thereafter, he worked in numerous capacities, including as a recruiter with the YMCA and the Boy Scouts, as a public speaker and writer, as a lobbyist for the Sioux, as a collector of ethnological specimens, and again for the government to revise Sioux allotment rolls. He and Elaine later opened a summer camp in New Hampshire for girls. ${ }^{47}$ Charles himself admitted that the family struggled financially. In a letter to his friend, fellow doctor and activist Carlos Montezuma, Eastman declared, "It seems you and I are brought into this life- to exert ourselves for a cause. Therefore, we must not give up. I have a large family to support, but they are great inspiration to me. I never have ... left my quiver empty. It seems that I am getting accustom[ed] to all emergencies." ${ }^{48}$ Elaine, however, did not sympathize with the limited options that Charles faced in his work. Instead her vision of womanhood and manhood began to veer away from that of her husband's.

At the same time Charles and Elaine might have evolved differently regard- 
ing racial and cultural views. Although in her memoirs she critiques those "strait-laced individuals" who rejected everything Native in the late nineteenth century, Elaine nevertheless supported the cornerstones of assimilation policy-Christian conversion, American education, and allotment of communally owned Indian lands. "Having lived at the heart of the issue for half a century," she wrote, "I deeply regret the folly of holding the tribes together in compact masses and teaching them dependence upon the federal government. It has, quite unnecessarily, kept the majority of Indians children and wards to this day." ${ }^{49}$ In the 1890 s Charles seems to have agreed with his wife. For example in 1895 he worked for the YMCA on the Pine Ridge Agency in South Dakota to encourage young Sioux Indians to accept Christ. He noted, "There are 7000 Indians on this reservation, and the wild dances and many of the degrading things are still in full force, and unchecked, to drag these young men down." He hoped to replace the traditional dances of the Sioux with "scientific and systematic sports." 50

As Charles aged, however, he rediscovered his Indian religious roots and became more critical of Christianity. In fact, by 1911, when he published The Soul of the Indian, he suggested that traditional Indian religion was truer to Christ's teachings than Christianity as practiced by most Americans. "It is my personal belief, after thirty-five years' experience of it," wrote Charles, "that there is no such thing as 'Christian civilization.' I believe that Christianity and modern civilization are opposed and irreconcilable, and that the spirit of Christianity and of our ancient religion is essentially the same." ${ }^{51}$ Indeed, in Charles's view:

It appears that not freedom or democracy or spiritual development, but material progress alone, is the evidence of "civilisation". The American Indian failed to meet this test, or rather, he made no attempt to meet it, being convinced that accumulation of property breeds dishonesty and greed, while concentration of population is abnormal and the mother of many evils, both physical and moral. ${ }^{52}$

As we shall see, Charles's opinion of Christianity and civilization would come to predominate in the 1920 s among a group of white primitivists.

Charles seemed particularly concerned that American civilization had unmanned Indian men. In fact, his writing is laden with references to manhood and manliness. As he defined it, "true manhood" meant a life of "physical activity and endurance." ${ }^{53} \mathrm{He}$ sought to rejuvenate Indian manhood and make known to Americans that the Indian "race has contributed some sterling traits to the American ideal," including "a model physique." He believed that if reformers "could awaken the old idea that no man can be a man without sound muscle, that no warrior can be a warrior, no hunter can properly be a hunter, 
without good, sound muscle," they could improve the lives of Indian men. $\mathrm{He}$ hoped that young Indian men would "hold together for developing their manhood, their character." Charles practiced what he preached. At Beloit College he spent three hours a day in physical exercises to keep himself fit. ${ }^{54}$

Clearly the Eastmans had veered apart from one another and not just for personal reasons. Elaine remained faithful to a vision of Indian assimilation that Charles outgrew and eventually challenged. Elaine became embittered by playing a backstage role once married. Similarly, Charles could not completely conform to Elaine's ideal of what a man should be, a provider for his wife and children. Instead, he defined manhood first as developing one's physical body so as to be a strong modern-day warrior.

Charles's view that Indian men embodied a true manhood became a powerful notion in the 1920s. This perspective became popular among a group of bohemian antimodernists who romanticized primitive people. Disillusioned with modern American society, they looked to primitive societies as model communities that could restore some of the values and lifestyles supposedly lost by modernization and industrialization. This group included writers and artists, many of whom settled in Taos and Santa Fe, New Mexico, in the years surrounding World War I. ${ }^{55}$

One of the most famous of the antimodernist refugees of this era was Mabel Luhan, born to a wealthy and prominent Buffalo family. After the death of her first husband, the birth of her only son, and a scandal involving an affair with her married gynecologist, Mabel traveled to Italy, where she married Edwin Dodge, a man she met on board ship. In the 1910s, Mabel returned to New York City and became active in the radical politics of her day. She opened a salon in her Fifth Avenue apartment where the great intellectuals and activists of the day regularly gathered. In 1917, having divorced Edwin and broken off her love affair with John Reed, Mabel rashly married the Russian-born painter Maurice Sterne. ${ }^{56}$

Mabel shortly regretted her hasty marriage and packed Maurice off to the Southwest on a solitary honeymoon where she had "heard there are wonderful things to paint. Indians." While Maurice honeymooned alone in Santa Fe, Mabel visited a medium in New York City who envisioned her "surrounded by many people ... dark people ... dark faces — they are Indians.” The psychic told Mabel, "You are to help them-you are for them." One night Mabel dreamed she "saw a large image of Maurice's head," and, as she gazed at his face, it "began to fade and another face replaced it, ... a dark face with wideapart eyes that stared at me with a strong look, intense and calm. This was an Indian face." A few days later a letter arrived in the mail from Maurice, asking Mabel, "Do you want an object in life? Save the Indians, their art-culturereveal it to the world!" 57 
Taking these developments as a mystical sign, Mabel soon joined her new husband in New Mexico. But Mabel disliked the company of other artists in Santa Fe and was intrigued instead by Taos, seventy-five miles to the north. Impulsively, on their first visit and before even viewing Taos in daylight, Mabel insisted that the couple rent part of a house there. Once settled into her new home, she walked daily to Taos Pueblo. One day a Pueblo woman, Candelaria Luhan, invited Mabel, Maurice, and Mabel's son into their home. Candelaria's husband, Tony, was playing a drum, his head bent over it intently. When he looked up Mabel "saw his face was the face that had blotted out Maurice's" in her dream. Mabel grew infatuated with Tony, and Tony returned her interest. Throughout Mabel's first winter and spring in Taos Tony often came to drum in her home. In the spring and summer Tony took Mabel and her family and friends on tours of the area. He encouraged her to buy a home and property in Taos. ${ }^{58}$

In August of 1918 Maurice returned to New York, leaving Mabel and Tony free to pursue their burgeoning romance. The new couple lived openly together, their unabashed adultery causing scandal in both white and Pueblo societies. When Mabel became involved in a nationwide effort to save Pueblo lands in the 1920s, her affair threatened to undermine the campaign. In 1923, at the urging of their white friends, Mabel and Tony divorced their spouses and married one another. Revealingly, it was more their adultery and cohabitation without marriage than the interracial quality of their liaison that caused many white Americans to view Mabel and Tony's relationship as scandalous. This suggests that a great shift in attitudes had occurred among at least some white Americans. ${ }^{59}$

Taos Pueblo, on the other hand, did take offense at Tony's relationship with a white woman and his abandonment of Candelaria. Once divorced from Tony, Mabel agreed to pay Tony's former wife thirty-five dollars a month for the rest of Candelaria's life. The Taos tribal council punished Tony in other ways; although he was permitted to keep his position on the tribal council, he was barred from participation in religious kiva ceremonies. Not until 1935 did Taos's cacique, or religious head, reverse this position. ${ }^{60}$ Taos Pueblo's reaction to the relationship suggests an important area for further research. So often focused on how white Americans viewed interracial marriage, scholars have not yet excavated the ways in which Indian communities and other nonwhite communities perceived and regulated such relationships.

In her memoirs Mabel presented her courtship with Tony in glowing, romantic terms, but she actually experienced many troubled times with him. In her book on the British writer D. H. Lawrence, Lorenzo in Taos, she dramatically lamented, "What incomprehensible aloneness for the white woman / Who crosses over into the Indian heart!" She confided to Lawrence that Tony 
gave her zest in life, "but so much spoils it. I suppose we must admit our different cultures - our surface lives - have taken different directions. So that there is practically nothing for us unavoidably to do together.... If we sit in a room, it is silence." ${ }^{11}$ She also revealed to her Jungian therapist, Frances G. Wickes, that Tony had pursued affairs with other women, including the painter Georgia O'Keefe. For her part Mabel also sought to seduce other men, including Lawrence and Jean Toomer, a mystic and writer connected with the Harlem Renaissance. ${ }^{62}$ Historians are at a loss to know how Tony perceived his relationship with Mabel because, unlike Mabel, he did not write his memoirs or leave behind any written evidence of his perspectives. We can only surmise from Taos Pueblo's actions that Tony sacrificed a great deal of his tribal affiliation due to his marriage to Mabel. Despite their troubles, however, the couple remained married the rest of their lives.

The symbolic power of their marriage may have sustained Mabel through the hard times. Unlike Elaine Goodale, who had accepted and promoted unions between white women and Indian men as a means to assimilate Indians into white society, Mabel rejected the goal of assimilation, both personally and politically. As an advocate for the Pueblos and other Indians in the 1920 s she condemned the federal policy of assimilation and campaigned for indigenous land rights and religious freedom. In order to preserve Pueblo culture she promoted Pueblo arts and crafts and sought to insulate the Pueblos from the "corrupting" influences of modern white society.

On a personal level Mabel wished to purge herself of "her people." "Was it possible for me to get away from [my people]," she queried, "and wash away from myself the taint of them, the odor of their sickness and their death? ... I hated them in myself and myself in them, and I longed to blot them out in this other." ${ }^{63}$ She sought to emulate the Pueblo Indians by cutting her hair in the fashion of Pueblo women and wearing a shawl about her shoulders Pueblostyle. When she returned from one of her visits to Taos Pueblo, she "assumed a bright noncommittal expression which I supposed was the way Indians looked. I wanted to be like them and felt, in an obscure way, that if I looked and acted the way they did, I would be." 64 As defined by Mabel, a marriage between an Indian man and a white woman no longer functioned as a means for the white woman to assimilate the Indian man and his race. Instead the Indian man might now save his white wife and her decaying society.

Despite her desire to marry Tony, to "go Native," and to heal modern American society with the values of Indian culture, Mabel did not wholeheartedly favor marriage between Indians and whites, not because it would sully the white race but because it would, in her mind, ruin the Indian race. In 1933 she confided to her old friend John Collier, an antiassimilationist reformer who 
became commissioner of Indian Affairs in the 1930s, "Although I married an Indian I did not do so when we were both young (and I don't believe in it for others). I cannot bring myself to change from my previous hope that the Indian culture may be saved as it cannot be if he [sic] becomes absorbed into the Mexican or the white races." ${ }^{65}$ Mabel's note to Collier reveals just how muddled her view of race was. In Mabel's view it seemed to be "blood" that determined Indianness. Nevertheless Mabel believed that she could virtually become an Indian through adopting Indian dress and hairstyle and by marrying an Indian man. She lived in an era in which the progressive faith in environmental nurture had waned and in which eugenics gained in popularity (even among leftists). Thus she could construct a contradictory view of race as determined by blood for Indians but volitional for whites. ${ }^{66}$

There are other documented examples of white women who found intimacy and companionship with Indian men in the 1910s and 1920s. In 1913 Maria Keller, an immigrant from Romania, married Carlos Montezuma, a Yavapai medical doctor and activist who was a close associate of Charles Eastman's. When Montezuma died in the 1920s, Maria married William Moore, a Pima man. ${ }^{67}$ Edith Warner, who in 1928 became a caretaker of a railway station at Otowi Bridge in New Mexico, befriended many Indians at nearby San Ildefonso Pueblo. An Indian man, Tilano, who helped her with projects around her home and the station, eventually came to live with her. Although Warner's biographer claims that "they were not man and wife," Edith and Tilano lived together in the same home and were clearly close companions, if not sexual partners, for the remainder of their lives. ${ }^{68}$ Carobeth Laird, while married to the anthropologist John Peabody Harrington, met and fell in love with George Laird, one of her husband's Chemehuevi informants. In the early 1920 Carobeth divorced her husband and married George. ${ }^{69}$

In the 1920 s other white women merely flirted with the idea of a sexual liaison with an Indian man. According to writer and New Mexico tour guide Erna Fergusson, it was common in the 1920 s to see "women novelists picturesquely distributing peacock-feathers among good-looking young Hopis" at the Hopis' Snake Dance. Erna Fergusson herself, if not openly pursuing young Indian men, saw the attraction. As she viewed an Indian dance Fergusson "watched one beautiful young dancer, posed perfectly on the balls of his feet, his body slim and straight like an arrow, wild and fawn-like even under baggy ... trousers." In dismay Fergusson "turned to an Indian Service man" sitting near her. "Why, oh why, does he wear trousers?" Fergusson wailed, "His body is so beautiful." The Indian Service man rebuked her sternly, "Young lady, ... don't talk like that to me. I've spent the best years of my life trying to get these fellows into pants." 70 
The allure of Indian men seems to have affected not just an elite group of bohemian women but other women as well. In a revealing letter to Maria Montezuma Moore, Gladys Brown, a woman who appears to have been a passing acquaintance, remarks on Moore's recent remarriage to "another Indian! ... How could it be otherwise?" speculated Brown. "You had such a wonderful Indian in Montezuma how could you marry a plain White Man, of course not. (I hope my father never sees that line)." Brown proceeded to share with Moore a "secret" that only her mother knew. "Sometime when you find a real honest to goodness Indian who is good capture him for me. Will I ever be so lucky not even being able to know any or to live near them and being so dreadfully backward in the bargain." Brown also told Moore that she loved Indian pictures but she only had two that were framed. "I cut all the Indians' pictures out of papers and magazines that I see the big ones I tack up on the walls of my bedroom ... every inch of wall covered." 71

Such interest in and flirtatiousness with Indian men by white women annoyed Mabel, who complained to her therapist that "Tony is so attractive to women. ... You cannot imagine how almost all women turn to him. He looks (and is) so somehow spiritual and magnetic at the same time.... They are attracted to him like bees to honey." 72 White reformers who were opposed to any such unions also noticed this phenomenon. Using a derogatory term for Indian men, in 1926 Clara True ridiculed these flirtatious white women as a "party of buck-struck society women." 73

Why did Mabel Dodge Luhan and a significant number of white women suddenly become so openly passionate about Indian men? Much of their new orientation can be attributed to the influence of an emerging anthropological theory - cultural relativism - that had been pioneered by Franz Boas and Elsie Clews Parsons, as well as a growing primitivist sentiment among many white Americans in the 1920s. Cultural relativists deemed Indian and other supposedly "primitive" cultures to be equal, not inferior, to white, AngloSaxon Protestant culture. Primitivists went even further; they regarded many Indian societies as superior to modern American society. Freud's new theories about sexuality and a loosening of late-Victorian sexual mores also coupled with changing notions of race to influence the new orientation of these white women. Building on Freud's theories, Mabel and other white women contended that modern Americans and Europeans had repressed their natural sexual instincts while primitive peoples suffered from no such unhealthy inhibitions. Describing a group of Taos Indians who came to dance at her house Mabel wrote, "Their brown bodies are beautiful, for every inch of them has a gleaming awareness as though their flesh is wholly awake." Mabel lamented that among whites, "Our bodies are deserted. We do not live in them and they are like abandoned houses." 74 
Mabel and, seemingly, other white women, also adopted a view of Indian manhood that closely correlated with Charles Eastman's. As she watched her first Pueblo dance Mabel asserted that "the sonorous drum fused the voices of the men and the volume of it all together was strong and good and very masculine." Mabel found this strong masculine essence lacking in modern white men, as she demonstrated in her portrayal of Maurice, her modern man, as "old and spent," his masculinity diluted. However, Tony, her "primitive," was "whole," "young," and "hard"- his "power unbroken." Thus Luhan equated masculinity with primitiveness and emasculation with modernity. In a letter to her friend Elizabeth Shepley Sergeant, Mabel in fact asserted that there was an "incompatibility between those emasculated religions and the virile religion of the Indian that has retained its vigor and its life just because it has, symbolically, a sexual basis." ${ }^{75}$ Not only were individual Pueblo men more masculine, but their entire religion was "virile." Interestingly, Charles Eastman's contention that Indian manhood was more masculine than white "civilized" manhood had become a commonly held assumption of the early twentieth century among some white women, particularly those of a bohemian background who were active in challenging and overturning the gender and race strictures of the late nineteenth century. In an era that extolled heterosexual sexuality, white women who took Indian lovers gave notice that they were no longer bound by the sexual inhibitions of their race and era.

In the cases presented here what might appear to be simple human attraction between individuals who happened to be classified as two separate races actually illuminates shifting conceptions of race and gender in the period from 1875 to 1935 . Up until the late nineteenth century, powerful social taboos, if not legal restrictions, proscribed marriages between white women and Indian men. Changes in ideas about race and gender in the late nineteenth century, however, opened the door a crack to more such unions. The notion that grew in popularity among most missionaries and reformers, in which perceived Indian inferiority was only due to environment and not to biology, made interracial marriage more thinkable, even desirable. The concurrent belief among reformers in white women's moral authority and ability to uplift "backwards" people further justified such marriages. But inherent contradictions within these two intertwined ideologies may have led not only to the downfall of the Eastmans' marriage but also to the creation of another set of notions about gender and race. As a reformer in the late nineteenth century Elaine Eastman had created a stimulating and fulfilling career for herself. Part of the message she was to convey to Indian families, though, was the ideal of the male as breadwinner and the female as homemaker. When she married Charles Eastman, the glaring contradiction between her actions and her pronouncements 
eventually came to haunt her. It can also be said that even as the ideology and policy of assimilation brought Elaine and Charles together, it also tore them apart. Charles became disenchanted with civilization and Christianity while Elaine generally maintained support for the assimilation agenda.

The breaking down of assimilation and moral authority that seems to have become embodied in Elaine and Charles's crumbling marriage opened the door wider for interracial marriages based on new notions of race and gender. A growing primitivist sentiment, a loosening of Victorian sexual mores, and a breakdown of the notion of female moral authority created a new justification for marriage between white women and Indian men. Mabel would not assimilate Tony; rather, she would learn from him and translate his Indian values to a failing American society. Further, Mabel would liberate herself as a woman through her connection with a truly masculine man.

The Eastmans' and the Luhans' marriages functioned not only as private affairs but as public embodiments of changing notions of race and gender. Studying how interracial couples presented themselves to a sometimes hostile, sometimes curious and voyeuristic American public can further enrich our understanding of the complex interworkings of racial and gender construction in American history.

\section{NOTES}

1. Kay Graber, ed., Sister to the Sioux: The Memoirs of Elaine Goodale Eastman, 188591 (Lincoln: University of Nebraska Press, 1978), 172; Charles Eastman, From the Deep Woods to Civilization (1916; reprint, Lincoln: University of Nebraska Press, 1977), 124. For a firsthand account of their marriage, see the monthly journal of the Women's National Indian Association, The Indian's Friend 3, no. 11 (1891): 3. It is common for scholars to refer to people by their last names. However, to avoid confusion in this article that deals with couples with the same last names, I have opted to refer to all of my major subjects by their first names. I also use the terms Native American, American Indian, and Indian interchangeably, as all have become acceptable terms to refer generally to the first peoples of North America. Where possible, however, in accordance with the wishes of most Indian people, I use tribal affiliation to more accurately identify individuals.

2. Mabel Dodge Luhan, Edge of Taos Desert: An Escape to Reality, vol. 4 of Intimate Memories (1937; reprint, Albuquerque: University of New Mexico, 1997), 193.

3. Peggy Pascoe, "Race, Gender, and Intercultural Relations: The Case of Interracial Marriage," Frontiers 12, no. 1 (1991): 5.

4. For laws and court cases, see Ian F. Haney López, White By Law: The Legal Construction of Race (New York: New York University Press, 1996); Byron Curti Martyn, 
"Racism in the United States: A History of the Anti-Miscegenation Legislation and Litigation" (Ph.D. diss., University of Southern California, 1979); David H. Fowler, Northern Attitudes Towards Interracial Marriage: Legislation and Public Opinion in the Middle Atlantic and the States of the Old Northwest, 1780-1930 (New York: Garland Publishing, 1987); Kathleen M. Brown, Good Wives, Nasty Wenches, and Anxious Patriarchs: Gender, Race, and Power in Colonial Virginia (Chapel Hill: University of North Carolina Press, 1996); Martha Hodes, White Women, Black Men: Illicit Sex in the Nineteenth-Century South (New Haven cT: Yale University Press, 1997); and Peggy Pascoe, "Miscegenation Law, Court Cases, and Ideologies of 'Race' in Twentieth-Century America," in Sex, Love, Race: Crossing Boundaries in North American History, ed. Martha Hodes (New York: New York University Press, 1999), 464-9o. For social attitudes, see David Smits, “'Squaw Men', 'Half-Breeds,' and Amalgamators: Late Nineteenth-Century Anglo-American Attitudes Toward Indian-White Race-Mixing," American Indian Culture and Research Journal 15, no. 3 (1991): 29-61; and Joel Williamson, New People: Miscegenation and Mulattos in the United States (New York: Free Press, 1980). For some studies focusing on black-white sex and intermarriage, see Hodes, White Women, Black Men; Williamson, New People; and Fowler, Northern Attitudes.

5. Katherine Ellinghaus is one of the few scholars to study this configuration in comparison with relationships between Aboriginal men and white women in Australia. See Katherine Ellinghaus, "Reading the Personal as Political: The Assimilationist Views of a White Woman Married to a Native American Man, 1880s-1940s," Australasian Journal of American Studies 18, no. 2 (1999): 23-41; and "Interracial Marriage and the Ideology of Assimilation: Hampton Institute, 1878-1923," Virginia Magazine of History and Biography 108, no. 3 (2000): 279-303.

6. For examples, see Noel Ignatiev, How the Irish Became White (New York: Routledge, 1995); Matthew Frye Jacobson, Whiteness of a Different Color: European Immigrants and the Alchemy of Race (Cambridge MA: Harvard University Press, 1998); David Roediger, The Wages of Whiteness: Race and the Making of the American Working Class (London: Verso, 1991), and Towards the Abolition of Whiteness: Essays on Race, Politics, and Working Class History (London: Verso, 1994); Alexander Saxton, The Rise and Fall of the White Republic: Class Politics and Mass Culture in Nineteenth-Century America (London: Verso, 1990); Reginald Horsman, Race and Manifest Destiny: The Origins of American Racial Anglo-Saxonism (Cambridge ma: Harvard University Press, 1981); and López, White By Law. I have used Lopez's concept of race as a socially and culturally "fabricated" phenomenon because it so ingeniously captures the nature of racial categorization.

7. For new studies of interracial sex and marriage, see Hodes, Sex, Love, Race. Other studies include Martyn, "Racism in the United States"; Fowler, Northern Attitudes; Brown, Good Wives; Hodes, White Women, Black Men; Williamson, New People; and Smits, "'Squaw Men.” 
8. George Frederickson, "Reflection on the Comparative History and Sociology of Racism," in Racial Classification and History, ed. E. Nathanial Gates (New York: Garland Publishing, 1997), 54.

9. For just a sampling of works in women's history and the history of sexuality that show the plasticity of gender, see John D'Emilio and Estelle Freedman, Intimate Matters: A History of Sexuality in America (New York: Harper \& Row, 1988); Gerda Lerner, The Creation of Patriarchy (New York: Oxford University Press, 1986); and Nancy F. Cott, The Bonds of Womanhood: “Woman's Sphere" in New England, 1780-1835 (New Haven ст: Yale University Press, 1977).

10. For examples of scholarly work that offer very little gender analysis of interracial relationships between Europeans and Indians, see Smits, "'Squaw Men;" Gary Nash, "The Hidden History of Mestizo America," in Hodes, Sex, Love, Race, 10-32; and Mark Alan Sigmon, "Heretics of Race: An Exploration of Indian-White Relationships in the Trans-Mississippi West, 1820-1850" (Ph.D. diss., University of California, Berkeley, 1995).

11. See Hodes, White Women, Black Men; Brown, Good Wives; and Paul Finkelman, "The Crime of Color," Tulane Law Review 67, no. 6 (1993): 2063-112, reprinted in E. Nathaniel Gates, ed., Racial Classification and History (New York: Garland Publishing, 1997), 1-50.

12. See Fowler, Northern Attitudes; Hodes, White Women, Black Men; Kathleen Brown, Good Wives; and Finkelman, "The Crime of Color."

13. Fowler, Northern Attitudes, 336-439. The colonies banning Indian-white intermarriage were Virginia, North Carolina, and New York. The territories or states banning Indian-white intermarriage were Arizona, Georgia, Idaho, Louisiana, Rhode Island, Maine, Massachusetts, Nevada, North Carolina, Oklahoma, Oregon, South Carolina, Tennessee, Virginia, and Washington. In some states mulattos were defined as children of either whites and blacks, blacks and Indians, or whites and Indians, so other colonies, states, and territories that banned marriage between mulattos and whites may have had laws in effect that restricted Indian-white intermarriage as well.

14. Brian W. Dippie, The Vanishing American: White Attitudes and U.S. Indian Policy (Middletown ст: Wesleyan University Press, 1982), 257-58.

15. John Demos, The Unredeemed Captive: A Family Story from Early America (New York: Alfred A. Knopf, 1994), 98-99, 157-64, 188-98, 213-37. For more on captivity and its cultural meanings, see June Namias, White Captives: Gender and Ethnicity on the American Frontier (Chapel Hill: University of North Carolina Press, 1993); and James Axtell, The Invasion Within: The Contest of Cultures in Colonial North America (New York: Oxford University Press, 1985).

16. Demos, The Unredeemed Captive.

17. John Ehle, Trail of Tears: The Rise and Fall of the Cherokee Nation (New York: Doubleday, 1988), 188-91; and Thurman Wilkins, Cherokee Tragedy: The Ridge Family 
and the Decimation of a People, 2d ed. (Norman: University of Oklahoma Press, 1986), 131-53.

18. See, for example, William J. Scheick, The Half-Blood: A Cultural Symbol in 19thCentury American Fiction (Lexington: University Press of Kentucky, 1979), 4. Coeur d'Alene Indian writer Janet Campbell Hale, herself a descendant of one of these marriages, objects strenuously to this view. She correctly points out that such a viewpoint, often reiterated by historians, devalues Native women by implying that no white man would willingly choose an Indian woman as his partner or wife, and that white men in frontier regions did so only out of desperation. See Hale's Bloodlines: Odyssey of a Native Daughter (New York: Harper, 1994), 125-40.

19. Richard Slotkin, Regeneration Through Violence: The Mythology of the American Frontier, 1600-1860 (Middletown ст: Wesleyan University Press, 1973), 58-65, 126.

20. Ehle, Trail of Tears, 189, 191-92. For discussions of feme covert, see Linda K. Kerber, No Constitutional Right to Be Ladies: Women and the Obligations of Citizenship (New York: Hill and Wang, 1998); Carol F. Karlsen, The Devil in the Shape of a Woman: Witchcraft in Colonial New England (New York: Vintage Books, 1987); and Brown, Good Wives.

21. Lydia Maria Child, Hobomok and Other Writings on Indians, ed. Carolyn Karcher (New Brunswick NJ: Rutgers University Press, 1986), 135-36, 137.

22. For more on the reform movement of the late nineteenth century, see Francis Paul Prucha, American Indian Policy in Crisis: Christian Reformers and the Indian, 18651900 (Norman: University of Oklahoma Press, 1976), and The Great Father: The United States Government and the American Indians, vol. 2 (Lincoln: University of Nebraska Press, 1984); Frederick Hoxie, A Final Promise: The Campaign to Assimilate the Indians, 1880-1920 (New York: Cambridge University Press, 1984); Margaret Jacobs, Engendered Encounters: Feminism and Pueblo Cultures, 1879-1934 (Lincoln: University of Nebraska Press, 1999); Valerie Mathes, "Nineteenth-Century Women and Reform: The Women's National Indian Association," American Indian Quarterly 14, no. 1 (1990): 1-18; and Helen M. Wanken, “'Woman's Sphere' and Indian Reform: The Women's National Indian Association, 1879-1901" (Ph.D. diss., Marquette University, 1981).

23. Graber, Sister to the Sioux, 22.

24. Graber, Sister to the Sioux, 114-20; and Raymond Wilson, Ohiyesa: Charles Eastman, Santee Sioux (Urbana: University of Illinois Press, 1983), 45-52.

25. Graber, Sister to the Sioux, 145-54.

26. Charles Eastman, Indian Boyhood (1902; reprint, New York: Dover Publications, 1971); Wilson, Ohiyesa, 13-20; and Marion Copeland, Charles Alexander Eastman (Ohiyesa) (Boise ID: Boise State University, 1978), 7-9.

27. C. Eastman, From the Deep Woods to Civilization. Eastman first published this book in 1916. See also Copeland, Charles Alexander Eastman, 9-11; and Wilson, Ohiyesa, 20-62. 
28. C. Eastman, From the Deep Woods to Civilization, 86-87, 105.

29. Graber, Sister to the Sioux, 155-175; C. Eastman, From the Deep Woods to Civilization, 92-115; and Wilson, Ohiyesa, 62.

30. Charles Eastman, Old Indian Days (New York: McLure Company, 1907), 51.

31. Fowler, Northern Attitudes Toward Inter-Marriage, 273-81; and Steven Selden, Inheriting Shame: The Story of Eugenics and Racism in America (New York: Teachers College Press, 1999).

32. Gustav Spiller, “The Problem of Race Equality," in Inter-Racial Problems: Papers from the First Universal Races Congress held in London in 1911, ed. Gustav Spiller (New York: Citadel Press, 1970), 38.

33. Dr. Jean Baptiste de Lacerda, "The Metis, or Half-Breeds, of Brazil," in Spiller, Inter-Racial Problems, 381.

34. Earl Finch, "The Effects of Racial Miscegenation," in Spiller, Inter-Racial Problems, 112.

35. Charles Eastman, "The North American Indian," in Spiller, Inter-Racial Problems, 375 .

36. C. Eastman, From the Deep Woods to Civilization, 186.

37. C. Eastman, "The North American Indian," 375.

38. Wilson, Ohiyesa, 163.

39. Charles Eastman and Elaine Goodale Eastman, Wigwam Evenings: Sioux Folk Tales Retold (1909; reprint, Lincoln: University of Nebraska Press, 1990), 164.

40. Elaine Eastman to Maria Montezuma Moore, 24 February 1936, Carlos Montezuma papers (Wilmington DE: Scholarly Resources, 1984), reel 9; and Wilson, Ohiyesa, 163-65.

41. Peggy Pascoe, Relations of Rescue: The Search for Female Moral Authority in the American West, 1874-1939 (New York: Oxford University Press, 1990); Barbara Epstein, The Politics of Domesticity: Women, Evangelism, and Temperance in NineteenthCentury America (Middletown ст: Wesleyan University Press, 1981); Barbara Welter, "She Hath Done What She Could: Protestant Women's Missionary Careers in the Nineteenth Century," American Quarterly 30, no. 5 (1978): 624-38; and Jacobs, Engendered Encounters.

42. Elaine Goodale Eastman, "All the Days," South Dakota Historical Review 2 (July 1937): 178 .

43. Speech of Elaine Eastman to Friends of the Indian, in Proceedings of the 13th Annual Meeting of the Lake Mohonk Conference of Friends of the Indian (New York: Lake Mohonk Conference, 1895), 92.

44. C. Eastman, Old Indian Days, 184.

45. E. Eastman, "All the Days," 182; Elaine Eastman to Mr. Winn, 7 April 1939, and Elaine Eastman to Harold G. Rugg, 19 April 1939, Charles Eastman alumni file, Dartmouth College. 
46. Graber, Sister to the Sioux, 173.

47. E. Eastman, "All the Days," 181, 182; Graber, Sister to the Sioux, 174; C. Eastman, From the Deep Woods to Civilization, 126-95.

48. C. Eastman to Carlos Montezuma, 2 January 1911, Montezuma papers, reel 2.

49. Graber, Sister to the Sioux, 85.

50. C. Eastman to Mr. C. K. Ober, 26 June 1895, Montezuma papers, reel 8.

51. Charles Eastman, Soul of the Indian (New York: Houghton Mifflin, 1911), 22, 24, $87-88$.

52. C. Eastman, "The North American Indian," 369.

53. C. Eastman, Indian Boyhood, 20. See also Charles Eastman, Indian Heroes and Great Chieftains (1918; reprint, Lincoln: University of Nebraska Press, 1991), 178. For more on the "crisis" of masculinity in the late nineteenth and early twentieth centuries, and its relationship to race, see Gail Bederman, Manliness and Civilization: A Cultural History of Gender and Race in the United States, 1880-1917 (Chicago: University of Chicago Press, 1995).

54. C. Eastman, as president of Society of American Indians, to "Friend and FellowIndian," 11 January 1919, Montezuma papers, reel 4; Letter from Charles Eastman to Friends of the Indians, Proceedings of the 17th Annual Meeting of the Lake Mohonk Conference of Friends of the Indian (New York: Lake Mohonk Conference, 1899), 66; and C. Eastman, From the Deep Woods to Civilization, 55.

55. Jacobs, Engendered Encounters.

56. Mabel Dodge Luhan, Movers and Shakers, vol. 3 of Intimate Memories (1936; reprint, Albuquerque: University of New Mexico Press, 1985); and Lois Palken Rudnick, Mabel Dodge Luhan: New Woman, New Worlds (Albuquerque: University of New Mexico Press, 1984).

57. Luhan, Movers and Shakers, 532, 533-34.

58. Luhan, Edge of Taos Desert, 20-44, 92-271 passim.

59. Mary Austin, Earth Horizon (Boston: Houghton Mifflin, 1932), 340; Mary Austin to Mabel Dodge, 4 April [1923], Mary Austin to Mabel Dodge, 29 April [1923], and Stella Atwood to Mabel Sterne, 8 January 1923, Mabel Dodge Luhan papers, Yale Collection of American Literature, Beinecke Rare Book and Manuscript Library, Yale University, New Haven, Connecticut.

60. Rudnick, Mabel Dodge Luhan, 155, 251.

61. Mabel Dodge Luhan, Lorenzo in Taos (New York: Alfred Knopf, 1932), 235, $276-$ 77. Lorenzo was Luhan's nickname for D. H. Lawrence, whom she invited to her home in the 1920 .

62. On Mabel's marital problems with Tony, see correspondence from Mabel Dodge Luhan to Frances G. Wickes, Frances G. Wickes papers, Library of Congress, Washington DC. See also Rudnick, Mabel Dodge Luhan, 155, 238-41. Rudnick claims Tony, on occasion, still slept with his first wife Candelaria in the 1920s, had an Anglo 
mistress in the 1930s in Carmel, and, in the 1940s and 1950s, had a Hispanic mistress. See also Ellen Kay Trimberger, "The New Woman and the New Sexuality: Conflict and Contradiction in the Writings of Mabel Dodge and Neith Boyce," in 1915, The Cultural Moment: The New Politics, the New Woman, the New Psychology, the New Art \& the New Theatre in America, ed. Adele Heller and Lois Rudnick (New Brunswick NJ: Rutgers University Press, 1991), 98-115.

63. Luhan, Edge of Taos Desert, 222.

64. Luhan, Edge of Taos Desert, 178, 179.

65. Mabel Dodge Luhan to John Collier, 30 November 1933, John Collier papers, microfilm edition (Sanford NC: Microfilming Corporation of America, 1980), reel 15.

66. See Jacobs, Engendered Encounters, 82-105; and Selden, Inheriting Shame.

67. Peter Iverson, Carlos Montezuma and the Changing World of American Indians (Albuquerque: University of New Mexico Press, 1982), 99-100.

68. Peggy Pond Church, The House at Otowi Bridge: The Story of Edith Warner and Los Alamos (Albuquerque: University of New Mexico Press, 1960).

69. Carobeth Laird, Encounter with an Angry God (Banning ca: Malki Museum Press, 1975; reprint, Albuquerque: University of New Mexico Press, 1993).

70. Erna Fergusson, Dancing Gods: Indian Ceremonials of New Mexico and Arizona (New York: Alfred A. Knopf, 1931), 162-63, 246-47.

71. Gladys Brown to Maria Montezuma Moore, 29 July 1924, Montezuma papers, reel 9.

72. Mabel Dodge Luhan to Frances Wickes, "Wednesday," from St. Joseph Sanatorium, Albuquerque, Wickes papers. Mabel also mentions how her white female friends were attracted to Tony in Edge of Taos Desert, 102.

73. Clara True to Samuel Brosius, 16 December 1926, Indian Rights Association papers, Historical Society of Pennsylvania, Philadelphia, microfilm edition (Glen Rock NJ: Microfilming Corporation of America, 1975), reel 43.

74. Luhan, Lorenzo in Taos, 193. For more on primitivism and its relation to changing sexual ideals, see Jacobs, Engendered Encounters.

75. Mabel Dodge Luhan to Elizabeth Shepley Sergeant, 10 June [1925], Collier papers, reel 5 . 